\title{
Antimicrobial and Antioxidant Activity of Endophyte Bacteria Associated with Curcuma longa Rhizome
}

\author{
Sulistiyani ${ }^{1^{*}}$, Tri Ardyati ${ }^{2}$, Sri Winarsih $^{3}$ \\ ${ }^{1}$ Master Program of Biology, Faculty of Mathematic and Natural Sciences, University of Brawijaya, Malang, Indonesia \\ ${ }^{2}$ Department of Biology, Faculty of Mathematic and Natural Sciences, University of Brawijaya, Malang, Indonesia \\ ${ }^{3}$ Department of Microbiology, Faculty of Medicine, University of Brawijaya, Malang, Indonesia
}

\begin{abstract}
Most cases of bacterial resistance towards antibiotics, encourage various efforts to gain new sources of antibiotics. Endophyte bacteria is a micoorganism has important role as the producer of bioactive compounds. Endophyte bacteria from Curcuma longa with antimicrobial and antioxidant activities have not been studied yet. Curcuma longa has been utilized as the main ingridients of traditional herbal medicines (jamu). The objective of this research was to investigate the antimicrobial and antioxidant activity of endophyte bacteria associated with Curcuma longa rhizome. Based on morphological characteristics of bacterial colonies, eight endophyte bacteria was isolates from Curcuma longa rhizome. Screening of endophyte isolate has antimicrobial activity was done using agar well diffusion method. The culture supernatant of each endophyte isolate was dropped on agar well against pathogenic bacteria Salmonella enterica ser. Typhi, Staphylococcus aureus and yeast Candida albicans. Three endophyte isolates $\mathrm{K}_{3}, \mathrm{~K}_{2}$ and $\mathrm{M}_{1 \mathrm{~b}}$ showed antimicrobial activity against pathogenic bacteria and yeast. Isolate $K_{3}$ showed strong antimicrobial activity againts $C$. albicans and $S$. aureus, however isolate $K_{2}$ and isolate $\mathrm{M}_{1 \mathrm{~b}}$ showed antimicrobial activity againts Salmonella enterica ser. Typhi and $S$. aureus, respectively. Those endophyte bacteria also had antioxidant activity shown by scavenging ability toward DPPH radical with consecutive percentage of isolate $\mathrm{K}_{3}(72.3 \%), \mathrm{K}_{2}(51.3 \%)$ and $\mathrm{M}_{1 \mathrm{~b}}(64.6 \%)$. Isolate $\mathrm{K}_{3}$ showed the highest antimicrobial and antioxidant activity. Based on biochemical characteristics using Microbact $24 \mathrm{E}$ kit, isolate $\mathrm{K}_{3}$ was identified as Paenibacilus alvei and isolate $\mathrm{K}_{2}$ as Enterobacter agglomerans.
\end{abstract}

Keywords: antimicrobial, antioxidant, Curcuma longa's rhizome, endophyte bacteria.

\section{INTRODUCTION}

Recent main health care issues include the rise of antibiotic resistances and the rise of chronic and degenerative disease in countries throughout the world regardless of income level. The rise of antimicrobial resistance need the discovery and/or production of novel antimicrobial. Antioxidants, that have capability scavenging free radicals, are known to play important roles in preventing the degenerative, ROS-linked diseases. As the human population growth and the increase awareness on healthy life, people prefer natural compounds. Thus, the exploration of novel source of natural bioactive compound is unavoidable. One of the most promising source of natural bioactive compound is endophyte [1].

Endophytes are microorganisms, often bacteria, actinomycetes or fungi that live in healthy plant tissue intercellularly and/or intracellularly without causing any apparent symptoms of disease. Endophyte bacteria are found in roots,

\footnotetext{
* Correspondence author:

Sulistiyani

Email : yaniprawiro@ymail.com

Address : Master Program of Biology, University of Brawijaya, Veteran Malang, 65145
}

tubers, rhizome, nodule, stems, leaves, flowers, ovules, seeds and fruits of various plant species. In general roots have greater numbers of endophytes than above ground tissues [2]. Many evaluations of bacterial endophytes have shown that they are widespread in numerous plant kingdom. A single plant may have several different endophyte bacteria. The structure of bacterial endophyte communitas are varied, dynamic overtime, and attributed to plant source, plant age, tissue type, time of sampling, season and environment [3].

The endophyte bacteria beneficial to its host by promote plant growth and yield, suppress pathogens, help plants to tolerate biotic stress or abiotic stresses, help to remove contaminants, solubilize phosphate, or contribute in fixing nitrogen. Endophytes bacteria are also known for the production of various classes of natural products and have been reported to exhibit a broad range of biological activity. It has reported over two thousands natural products have been isolated from endophytes associated with medicinal plants, including alkaloids, flavonoids, glycosides, phenolic acid, xanthones, steroids, terpenes, tetralones, coumarins, quinones, lactone, polysaccharide, peptides. Such bioactive 
metabolites are found to apply as agrochemicals like insecticidal, growth-promoting, and their potential in the pharmaceutical like antibiotics, antioxidants, antitumor, antidiabetics, antiparasitics, antithrombotic, anticancer and immunosuppressants agents [4].

Medicinal plant is well known as source of precious bioactive compound. Endophytes that have long time associate with medicinal plant may participate in metaboloc pathway or gain some genetic information to produce specific bioactive compound similar to the host plant. Plant that have ethnobotanical history should be sourced of endophyte microbe. Therefore, it is needed and important to study and explore medicinal plants and endophyte microbes that live in [4]. Curcuma longa's rhizome, commonly called as turmeric has been widely used as a spice and has a long history of medicinal use in the treatment of a variety of human diseases especially in Asia regions. This study was aimed to analyze the antimicrobial and antioxidant activity of endophyte bacteria associated with turmeric rhizome.

\section{MATERIALS AND METHODS \\ Study Area}

Sample of turmeric rhizomes were collected from Mondo Village, Mojo District, Kediri Regency. The soil type in the research site is aluvial, along the area of Brantas Watershed. Soil acidity in the plant site is 6.34. Optimum pH of soil for most plants range $5.5-7.0$ and nutrient will adsorbed well in the range $\mathrm{pH} 5.5-6.5$ [5]. Refer to the soil $\mathrm{pH}$ at the sample site, it has qualified for the plant to grow well. Healthy ten months old plants were selected as source of rhizome for endophyte bacteria isolation.

\section{Surface Sterilization of Turmeric rhizome}

Rhizomes of turmeric were washed with running tap water. The procedure includes sequential immersion of rhizomes parts in $70 \%$ ethanol for 3 minutes, sodium hypochlorite $2 \%$ for $5 \mathrm{mi}$ nutes and $70 \%$ ethanol for 30 seconds, then rhizomes was washed using sterilized distilled water for five times [6]. The last twice washing solutions were plated on Nutrient Agar (NA) to confirm the effectiveness of sterilization treatments. The surface of turmeric rhizomes were pilled out using aseptic technique and the inner tissues of rhizomes were macerated using a sterile mortar and pestle [7].

\section{Isolation of Endophyte Bacteria from Curcuma longa Rhizome [8,9]}

Total of $10 \mathrm{~g}$ turmeric rhizomes were extracted then performed a serial dilution in saline solution $(0.85 \% \mathrm{NaCl})$ and plated out in Nutrient Agar (NA) to recover endophyte bacteria present in the rhizome. All the plates were incubated at $28-30^{\circ} \mathrm{C}$ (room temperature) for 48 hours. The isolated bacteria were preliminary characterized according to their morphological characteristics. The distinct colony types were picked up from Nutrient Agar (NA) plates and were purified through three rounds of streaking and single colony was selected an refresh in the same medium.

\section{Test Microorganisms}

Pathogenic strain yeast of Candida albicans, Gram-positive bacteria Staphylococcus aureus and Gram-negative Salmonella enterica ser. Typhi clinical isolates were used as test microorganism in this study. All pathogenic strains were obtained from Department of Microbiology, Medical Faculty, University of Brawijaya. After 18-24 hours of incubation at $37^{\circ} \mathrm{C}$ (for bacterial strains) in NA and $30^{\circ} \mathrm{C}$ (for yeast strain) in PDA, a loopful of each test strains was suspended in sterile distilled water water until obtained $1 \times 10^{6}$ cfu. $\mathrm{mL}^{-1}$ for bacteria and $10^{5}$ cfu. $\mathrm{mL}^{-1}$ for yeast.

\section{Assays of Antimicrobial Activity}

Isolated endophyte bacteria from turmeric rhizomes were cultured in $5 \mathrm{~mL}$ Nutrient Broth (NB) medium at room temperature $\left(28-30^{\circ} \mathrm{C}\right)$ for five days. After five days, culture medium was centrifuged at $4000 \mathrm{rpm}$ for 15 minutes and supernatant was screened for antimicrobial activity by agar-well diffusion technique on NA media that was previously seeded with test pathogens. Supernatant $(50 \mu \mathrm{L})$ was added into wells $(7 \mathrm{~mm})$ formed by cork borer on the NA medium [10]. Sterile NB was set as control. As a positive control for antimicrobial activity towards test microorganism, we used amoxicillin antibiotic dose 10 $\mu \mathrm{g} \cdot \mathrm{mL}^{-1}$ [11] for S. enterica ser. Typhi and dose 25 $\mu \mathrm{g} \cdot \mathrm{mL}^{-1}$ [12] for S. aureus. While for the antimicrobial activity on yeast, we used anti fungal nystatin $12 \mu \mathrm{g} \cdot \mathrm{mL}^{-1}$ as positive control [13]. The plates were incubated in suitable temperatures for 24-48 hours; the zone of inhibition was measured and recorded. 


\section{Assay of Antioxidant Activity by Scavenging DPPH Free Radical}

Endophyte bacteria culture (in NB medium) were centrifuged at $4000 \mathrm{rpm}$ for 15 minutes, $4^{\circ} \mathrm{C}$ and then the supernatants were assayed their antioxidant activity by scavenging DPPH free radical methode [14] described with any modification. The supernatant $(0.5 \mathrm{~mL})$ was added to $3 \mathrm{~mL}$ of $0.1 \mathrm{mM}$ DPPH in methanol solution. Methanol $1.5 \mathrm{~mL}$ was then added thus the final volume of solution was $5 \mathrm{~mL}$. For control, supernatant of each sample was replaced by steril Nutrient Broth (NB). Methanol was used as blank. Discoloration of DPPH radical solution was measured at $517 \mathrm{~nm}$ in triplicate after incubation in the dark for 5 hours. Ascorbic acid was used as the positive control. Percentage of scavenged DPPH radical was calculated using following formula

$$
\text { \% Scavenging }=\left[\frac{A_{0}-A_{1}}{A_{0}}\right] * 100
$$

$A_{0}$ is the absorbance of control and $A_{1}$ is the absorbance of sample (supernatant of endophyte bacteria culture) or standard. Ascorbic acid was taken at various concentrations as a known antioxidant for comparative analysis. Then the percentage of scavenging were plotted against respective concentrations used, and from the graph, $\mathrm{EC}_{50}$ was calculated.

\section{Statistical analysis}

The experimental results of biological activity tests were expressed as mean \pm standard deviation (SD) of three replicates. The results were processed using Microsoft Excel 2007 and SPSS software. The data of antimicrobial activity assay results was analyzed using Kruskal-Wallis test followed by t-test and Tukey test whereas antioxidant activity using Anova following Tukey test.

\section{RESULTS AND DISCUSSION}

Based on the morphology characteristics of colony, we obtained eight isolates $\mathrm{K}_{1}, \mathrm{~K}_{2}, \mathrm{~K}_{3}, \mathrm{~K}_{4}$, $M_{1 a}, M_{1 b}, M_{5}$ and $M_{6}$ of endhopytes bacteria. Each pured isolate was tested further for the antimicrobial and antioxidants activities.

\section{Antimicrobial Activity}

Three of eight isolates of turmeric endophyte bacteria has inhibition activity towards pathogenic test microorganism. Isolate $\mathrm{K}_{3}$ inhibit the pathogenic yeast $C$. albicans (Fig. 1a) and pathogenic bacteria S. aureus (Fig. 1b). Otherwise, isolate
$\mathrm{K}_{2}$ inhibit the pathogenic bacteria Salmonella enterica ser. Typhi (Fig. 1C) and isolate $M_{1 b}$ inhibit S. aureus (Fig. 1d).
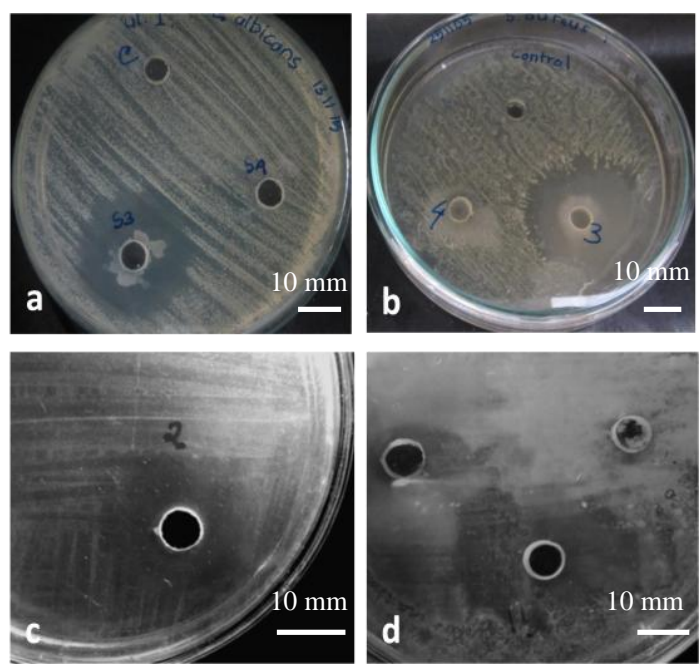

Figure 1. Inhibition zone of endophyte bacteria isolates Isolate $\mathrm{K}_{3}$ towards Candida albicans (a) and Staphylococcus aureus (b); Isolate $\mathrm{K}_{2}$ towards Salmonella enterica ser.Typhi (c); Isolate $\mathrm{M}_{1 \mathrm{~b}}$ towards Staphylococcus aureus (d).

The results showed that the inhibition zone of isolate $K_{3}$ towards $C$. albicans was greater than antifungal nystatin $\left(12 \mu \mathrm{g} \cdot \mathrm{mL}^{-1}\right)$. It also showed similar results for inhibition zone of isolate $K_{3}$ to $S$. aureus, which is greater than amoxicilin $(25$ $\mu \mathrm{g} \cdot \mathrm{mL}^{-1}$ ) and isolate $\mathrm{K} 2$ to Salmonella enterica ser. Typhi than amoxicilin $\left(10 \mu \mathrm{g} \cdot \mathrm{mL}^{-1}\right)$. Otherwise, the inhibition zone of isolate $\mathrm{M}_{1 b}$ to $S$. $a u$ reus was relatively similar to the inhibition zone of amoxicillin (25 $\left.\mu \mathrm{g} \cdot \mathrm{mL}^{-1}\right)$ (Fig 2).

Microbes produce any substance for defense systems or survival mechanism. These include antibiotics, bacteriocins, metabolic by-products, lytic agents, numerous types of protein exotoxins, and short chain fatty acid [15]. This study found that Isolate $K_{3}$ and $M_{1 b}$ (Gram positive bacteria ) showed inhibition of growth towards the pathogenic bacteria $S$. aureus as Gram-positive bacteria and showed no inhibition towards Gram-negative bacteria $S$. enterica ser. Typhi. In contrast, isolate $\mathrm{K}_{2}$ showed inhibition to Gram- negative bacteria $S$. enterica ser. Typhi and showed no inhibition to the Gram-positive bacteria $S$. aureus and yeast $C$. albicans. These properties are similar or corresponding to the nature of bacteriocins that they have a relatively narrow killing spectrum and are toxic only to bacteria closely related to the producing strain. But further test is needed to confirm that the 
substance is bacteriocin. In addition more than 99\% of bacteria can produce at least one bacteriocin and within a species tens or even hundreds of different kinds of bacteriocins are present [15].

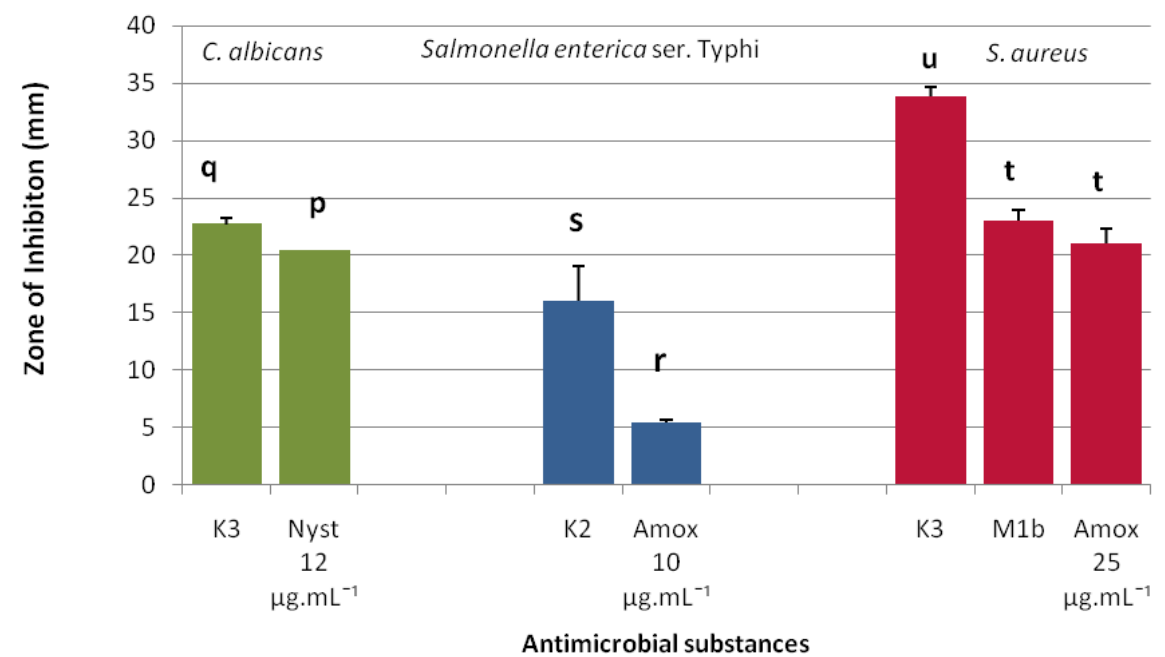

Figure 2. Antimicrobial Activity of Endophyte Bacteria Turmeric Rhizomes towards the Pathogenic Test Microorganism

\section{Antioxidant Activity}

The test of antioxidant activity on the eight isolates of endophyte bacteria showed that all isolates has the ability of scavenging to DPPH radical (Fig. 3). Three isolates with the highest antioxidant activity are isolate $K_{3}, K_{2}$, and $M_{1 b}$. Bacterial growth curve were made for the three isolates to obtain optimum time for sampling to test the antioxidant activity.

Antioxidant compound produced by the endophyte bacteria, as reported by scholar, is consisted of various substances. Antioxidant substances produced by endophyte bacteria are EPS [16], surfactin [17], L-asparaginase [18], carotenoid pigment [19], and several enzymes [20]. Most of the compounds were produced maximally at the end of exponential phase. Thus the sample for antioxidant activity was collected at the $14^{\text {th }}$ hour (the end of exponential phase).
Before the test of antioxidant activity, OD of liquid culture of endophyte bacteria was equated. The test of antioxidant activity showed that isolate $K_{3}$ has the highest ability of antioxidant activity compared to the other two isolates (Table 1 ) and then the $\mathrm{EC}_{50}$ of $\mathrm{K}_{3}$ isolate wias determined.

Efficient Concentration or $\mathrm{EC}_{50}$ value is defined as the concentration of substrate that causes $50 \%$ loss of the DPPH activity (colour)[21]. Isolate $\mathrm{K}_{3}$ supernatant had $\mathrm{EC}_{50}$ value 70.26 $\mu \mathrm{L} . \mathrm{mL}^{-1}$ and vitamin $\mathrm{C}$ (as standard) had $\mathrm{EC}_{50}$ value $3.71 \mu \mathrm{g} \cdot \mathrm{mL}^{-1}$. In this study isolate $\mathrm{K}_{3}$ supernatant was still in original liquid and had not evaporated yet or extracted in to concentrate, so it was intelligible that the $\mathrm{EC}_{50}$ value was too lower than vitamin C. For next study may be required further processing of the supernatant.

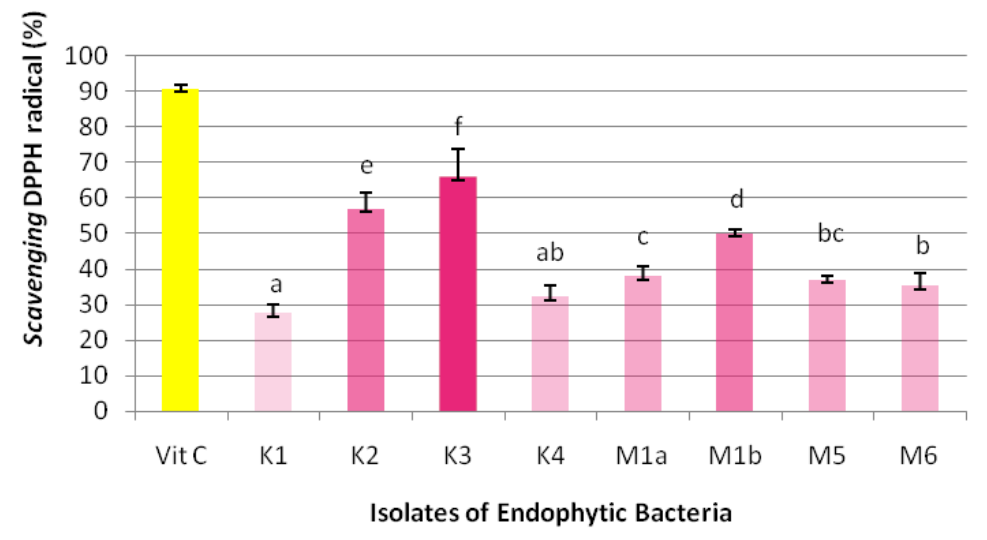


Figure 3. Antioxidant Activity of Curcuma longa Endophyte Bacteria Isolates

Tabel 1. Antioxidant activity of 3 isolates

\begin{tabular}{cll}
\hline No & Isolates & Scavenging DPPH radical (\%) \\
\hline 1 & $\mathrm{~K}_{2}$ & $51.3 \pm 3.1$ \\
2 & $\mathrm{~K}_{3}$ & $72.0 \pm 1.7$ \\
3 & $\mathrm{M}_{1 \mathrm{~b}}$ & $64.7 \pm 2.5$ \\
\hline
\end{tabular}

Note: Each value is represented as mean $\pm S D(n=3)$

\section{Species Identification}

Isolates $\mathrm{K}_{3}$ and $\mathrm{K}_{2}$ had both antimicrobial and antioxidant activity significantly, therefore need to characterize these isolates furthermore. Isolate $K_{3}$ and $K_{2}$ was characterized based on the biochemical characteristic using Kit Microbact System 24E. Biochemical characteristics of isolate $\mathrm{K}_{2}$ were analyzed by the software Microbact System 24E and isolate $K_{3}$ were analyzed refer to Identification flow chart from Microbiology Laboratorium, The University of Ottawa Canada base on Bergey's Manual of Determinative Bacteriology [22]. The results of characterization showed that isolate $\mathrm{K}_{2}$ was assumed as Enterobacter agglomerans with 99.9\% similarity, whereas isolate $\mathrm{K}_{3}$ is Bacillus alvei or Paenibacillus alvei with $91.2 \%$ similarity.

Paenibacillus alvei are rod-shaped, Grampositive, motile, spore-forming , catalase-positive bacteria and grow on simple media (NA/NB). Paenibacillus alvei are common found in honeybee colonies, soil, milk, mosquito larvae, the wax mot, humans and very rarely pathogenic for vertebrates. It has reported that Paenibacillus alvei produce antimicrobial substance: paenibacillin $P$ and paenibacillin N [23], peptide AN5-1 [24], cyclic lipopeptides [25], depsipeptide [26]. Some of the antimicrobial substance show active againts pathogen $S$. aures and $C$. albicans $[23,24,26,27]$ and consistent with this findings, this study showed endophyte bacteria from Curcuma longa's rhizome, isolate $\mathrm{K}_{3}$ that assumed as Paenibacillus alvei show antimicrobial activity to $S$. aureus and $C$. albicans. Isolate $\mathrm{K}_{3}$ also show antioxidant activity, it promote previous research that Paenibacillus alvei's metabolite have antioxidant activity Exopolysaccarides (EPS) [16,28,29]. Enterobacter agglomerans are rod shape, Gram negative, motile, non-sporforming bacteria. These bacteria first were isolated from plants, vegetable, fruits, seeds, and they are also commonly found in the ecological niches such as water, soil, sewage, feculent material, foodstuffs, clinical specimens [30]. It has reported that Enterobacter agglomerans produce antimicrobial substance that have inhibition growth to any pathogen bacteria and fungi. Some of them have inhibition growth to Salmonella sp. like herbicolin O [31], phenazine [32], and consistent with these finding, isolate $\mathrm{K}_{2}$ that assumed as Enterobacter agglomerans has antimicrobial activity to Salmonella enterica ser.Typhi. Isolate $\mathrm{K}_{2}$ also has antioxidant activity, it promote previous research that Enterobacter agglomerans has free radicalsscavenging ability [33].

\section{CONCLUSION}

The study obtained eigth isolates of endophyte bacteria from the Curcuma longa rhizomes. Three isolates of endophyte bacteria have antimicrobial activity, i.e. isolate $K_{3}$ to $C$. albicans yeast and $S$. aureus bacteria; isolate $K_{2}$ to $S$. enterica ser. Typhi, and isolate $M_{1 b}$ to $S$. aureus. All isolates of endophyte bacteria from Curcuma longa rhizomes has the antioxidant activity. The highest antioxidant and strong antimicrobial to Gram positive pathogenic bacteria activity was showed by isolate $K_{3}$ which identified as Paenibacillus alvei. The strong antimicrobial activity to Gram negative pathogenic bacteria and had high relative antioxidant activity was showed by Isolate $\mathrm{K}_{2}$ which identified as Enterobacter aglomerans by biochemical characterization.

\section{REFERENCES}

[1] Bintang, M., U.M.S. Purwanto, D.E. Kusumawati, J.J. Yang. 2015. Study of endophytic bacteria as novel source of antioxidant agent based on GC-MS Analysis. Int. J. Chem. Environ. Biol. Sci. 3(5). 368-369

[2] Anjum, N., R. Chandra. 2015. Endophyte bacteria: optimizaton of isolation procedure from various medicinal plants and their preliminary characterization. Asian J. Pharm. Clin. Res. 8(4). 233-238.

[3] Zinniel, D.K., P. Lambrectht, N.B. Harris, Z. Feng, D. Kuczmarski, P. Higley, C.A. Ishimaru, A. Arunakumari, R. G. Barletta, A.K. Vidaver. 2002. Isolation and characterization of endophyte colonizing bacteria from agronomic crops and prairie plants. Appl. Environ. Microbiol. 68(5). 2198-2208.

[4] Huawei, Z., C. Ying, X. Bai. 2014. Advancement in endophyte microbes from medicinal plants. Int. J. Pharm. Sci. Res. 5(5). 1589-1600.

[5] Perry, L. 2016. pH for the Garden. University of Vermont, Extension Department of Plant 
and Soil Science. Available at: https:// pss.uvm.edu/ppp/pubs/oh34.htm.

[6] Ratti, R.P., N.F.G. Serrano, C.O. Hokka, C.P. Sousa. 2008. Antagonistic propertis of some microorganisms isolated from Brazilian tropical savannah plants against Staphylococcus coagulase-positive strain. J. Venom. Anim. Toxins incl. Trop. Dis. 14(2). 294-302.

[7] Sulistiyani, T.R., P. lisdiyanti, Y. Lestari. 2014. Population and diversity of endophytic bacteria associated with medicinal plant Curcuma zedoaria. Microbiol. Indonesia. 8. 65-72.

[8] Pranoto, E., G. Fauzi, Hingdri. 2014. Isolation and characterization of Endophyt Bacteria on highland productive and Young Tea Plant (Camellia Sinensis (L.) O. Kuntze) GMB 7 Clone. Biospecies. 7(1). 1-7.

[9] Wulandari, H., Zakiatulyaqin, Supriyanto. 2012. Isolation and antagonistic test of endophytic bacteria from pepper (Piper nigrum I.) againt velvet blight pathogen (Septobasidium sp.). J. Perkebunan dan Lahan Tropika. 2(2). 23-31.

[10] Tawiah, A., S.Y. Gbedema, F. Adu, V.E. Boamah, K. Annan. 2012. Antibioticproducing microorganism from River Wiwi, Lake Bosomtwe and the Gulf of Guinea at Doakor Sea Beach, Ghana. Bio Med. Central Microbiol. 12(234). 1-8.

[11] Agricultural Research Service, United States Department of Agriculture (USDA). 2016. Table Breakpoints Used for Susceptibility Testing of Salmonella and E. coli. Available at: https://www.ars.usda.gov/ARSUserFiles /60400520/NARMS/ABXSalm.pdf.

[12] Sahputera, A. 2014. Uji efektifitas ekstrak madu karet dalam menghambat pertumbuh an S. aureus. Research Report. State Islamic University of Jakarta.

[13] Ellabib, M.S., I.A. El Jariny. 2001. In vitro activity of 6 antifungal agents on Candida species isolated as causative agents from vaginal and other clinical specimens. Saudi Med. J. 22(10). $860-863$.

[14] Afify, A.M.M.R., R.M. Romeilah, S.I.M. Sultan, M.M. Hussein. 2012. Antioxidant activity and biological evaluations of probiotic bacteria strains. Int. J. Academic Res. Part A. 4(6). 131-139.

[15] Riley, M.A., M.A. Chavan. 2007. Bacteriocins: ecology and evolution. Springer. Verlag Berlin Heidelberg.
[16] Liu, J., J.G. Luo, H. Ye, Y. Sun, Z.X. Lu, X.X. Zeng. 2009. Production, characterization and antioxidant activities in vitro of exopolysaccharides from endophyte bacterium P. polymyxa EJS - 3. Carbohydr. Polym. 78. 275-281.

[17] Yalçın, E., K. Çavuşoğlu. 2010. Structural analysis and antioxidant activity of a biosurfactant obtained from Bacillus subtilis RW-I. Turkish J. Biochem. 35(3). 243-247.

[18] Nongkhlaw, F.M.W., S.R. Joshi. 2015. Lasparaginase and antioxidant activity of endophytic bacteria associated with ethnomedicinal plants. Indian J. Biotech. 14. 59-64.

[19] Mohana, D.C, S. Thippeswamy, R.U. Abhishek. 2013. Antioxidant, antibacterial, an ultraviolet protective properties of carotenoids isolated from Micrococcus spp. Radiat. Prot. Environ. 36(4). 168-174.

[20] Li, S., Y. Zhao, L. Zhang, X. Zhang, L. Huan., D. Li, C. Niu, Z. Yang, Q. Wang. 2012. Antioxidant activity of Lactobacillus plantarum strains isolated from traditional. Chinese foods. Food Chem. 135. 19141919.

[21] Molyneux, P. 2004. The use of the stable free radical diphenylpicrylhydrazyl for estimating antioxidant activity. Songklanakarin J. Sci. Technol. 26(2). 211-219.

[22] Microbiology Laboratorium, The University of Ottawa Canada. 2016. Identification Flow Chart - Bergey's Manual of Determinative Bacteriology. Available at: https://mysite. science.uottawa.ca/jbass/mirolab/IDFlowch arts.

[23] Anandaraj, B. 2008. Co-Production of two new peptide antibiotics and specific protease by a bacterial isolate Paenibacillus alvei NP 75, through ribosomal and nonribosomal mediated protein synthesis machinery. Master Thesis. Faculty of Technology. Anna University, Chennai.

[24] Alkotaini, B., N. Anuar, A.A.H. Kadhum, A.A.A. Sani. 2013. Detection of secreted antimicrobial peptides isolated from cellfree culture supernatant of Paenibacillus alvei AN5. J. Indian Microbiol. Biotechnol. 40. 571-579.

[25] Knolhoff, A.M., J. Zheng, McFarland, A. Melinda, Y. Luo, J.H. Callahan, E.W. Brown. 2015. Identification and structural characterization of naturally-occuring broad-spectrum cyclic antibiotics isolated 
from Paenibacillus. J. Am. Soc. Mass Spectrometry. 26(10). 1768-1779.

[26] Chevrot, R., S. Didelot, L. Van den Bossche, F. Tambadou, T. Caradec, P. Marchand, E. Izquierdo, V. Sopéna, E. Rosenfeld. 2013. Probiotics Antimicrob. Proteins. 5(1). 18-25.

[27] Pancevska, N.A, I. Popovska, K. Davalieva, J. Kunguloski. 2016. Screening for antimicrobial activity of Bacillus subtilis and Paenibacillus alvei isolated from rotten apples compost. Acta Microbiologica Bulgarica. January. 56-64.

[28] Aziz, S.M.A., H.A. Hamed, M. Fadel, M.E. Moharam. 2015. Properties and role of exopolysaccharides produced by Paenibacillus alvei NRC14 for cell protection. J. Appl. Sci. 1(3. 35-47.

[29] Selim M. S., S.S. Mohamed, R. H. Shimaa, M.E. El Awady, O.H. El Sayed. 2015. Screening of bacterial antioxidant exopolysaccharides isolated from Egyptian habitats. J. Chem. Pharm. Res. 7(4). 980986.

[30] Quecine, M.C., W.L. Araujo, P.B. Rossetto, A. Ferreira, S. Tsui, P.T. Lacava, M. Mondin, J.L. Azevedo, A.A. Pizzirani-Kleinera. 2012. Sugarcane growth promotion by the endophytic bacterium Pantoea agglomerans 33.1. Appl. Environ. Microbiol. 78. 7511-7518.

[31] Ishimaru, C.A., E.J. Klos, R.C. Brubaker. 1988. Multiple antibiotic production by Erwinia herbicola. Dis. Control Pest Manage. 78(6). 746-750.

[32] Lim, J.A., D.H. Lee, B.Y. Kim, S. Heu. 2014. Draft genome sequence of Pantoea agglomerans R190, a producer of antibiotics against phytopathogens and foodborne pathogens. J. Biotechnol. 188. 7-8.

[33] Wang, H., X. J. Jiang, H. Mu, X. Liang, H. Guan. 2007. Structure and protective effect of exopolysaccharide from P. Agglomerans strain KFS-9 against UV radiation. Microbiol. Res. 162. 124-129. 